\title{
Types of Interlanguage Phraseological Correspondences (Based on English and Turkish Languages)
}

\author{
Zulfiia Khanifovna Fazlyeva ${ }^{1}$ \\ ${ }^{1}$ Department of Contrastive Linguistics and Linguadidactics, Institute of Philology and Cross-cultural \\ Communication of Kazan (Volga region) Federal University, Kazan, Republic of Tatarstan, Russian Federation \\ Correspondence: Zulfiia Khanifovna Fazlyeva, Department of Contrastive Linguistics and Linguadidactics, \\ Institute of Philology and Cross-cultural Communication of Kazan (Volga region) Federal University, Kazan, \\ Republic of Tatarstan, Russian Federation. E-mail: hanifovna@gmail.com; zulkin66@mail.ru
}

\author{
Received: March 11, 2015 Accepted: March 30, 2015 Online Published: May 22, 2015 \\ doi:10.5539/res.v7n9p1 URL: http://dx.doi.org/10.5539/res.v7n9p1
}

\begin{abstract}
Contrastive study of phraseology is important for general linguistic problematics, theory and practice of translation, interpreting lexicography and teaching foreign languages. We can state similarities and differences in phraseology of different languages based on current comparative studies. Many linguists use material of non-kindred languages in comparative studies. The objective of such researches is detection of both general features - universals common for any language and differential features typical for individual languages. The distinctive feature of phraseological units' correlation is that phraseological units are more complex than their components both by structure and meaning, it also should be mentioned the infrequency of the "form-meaning" relation. The objective of the paper is distinguishing and studying two phraseological groups of English and Turkish languages associated with the notion of "family" that, to the best of our knowledge, weren't studied before in each of languages separately and, particularly, in a comparative way. The study endeavors to correlate PU in both languages by basic parameters in order to define the universal and the differential, and also detect inter-linguistic equivalences and compensatory mechanisms in the area of difference.

Results of comparative study of PU contribute to distinguishing general and specific features of their structural models, detecting facts of one language system influence on the other, and also detecting regularities in PU translation from one language into the other.
\end{abstract}

Keywords: phraseological units, contrastive linguistics, full phraseological equivalence, partial phraseological equivalence, zero phraseological equivalence, analogues, lacunas

\section{Introduction}

Incentive for development of phraseological fund of any languages is productive process of formation of various modifications of PU. Linguistic literature offers different classifications of PU by the degree of equivalency.

There are several types of correspondences to imaginative phraseological units of the original. Phraseological equivalents are the first type of correspondences. When these correspondences are used, the entire complex of translated unit's meaning is preserved. In this case the translated phraseological unit coincides with the phraseological unit of compared language by all characteristics: "strike the iron while it is hot"- "Куй железо, пока горячо". However phraseological equivalents are few.

Phraseological units of the second type are so-called phraseological analogy. In this case the translation unit can be based on different image: "a bird in the hand is worth two in the bush"- "A titmouse in hand is better than a crane in the sky", etc. The use of such correspondence provides sufficiently high degree of equivalence. However, this type of translation is irrelevant when a phraseological unit has poignant national nuance in translating language. As a rule, translation conveys what is said by a foreign author of original text, and it would be strange if, for example, some English lord claims that you shouldn't "take your samovar to Tula" (carry coals to Newcastle) (Vinogradov, 2001).

The third type of phraseological correspondences is called zero equivalence or lacunarity. Translation of such phraseological units is made using calquing: "The grass is always greener on the other side of a fence". Calques make it possible to keep image of the original that is of prime importance in literary translation. Creating a 
correspondence-calque, the translator should be confident that the image of original unit is motivated enough and its reproduction in translation will allow the recipient of translation to understand conveyed figurative meaning (Zvegintsev, 1981). The following calked fixed phrase is clear enough: Он недостоин и воду таскать для нее (He is not fit to carry water for her), and foreign origin of the calque "ставить телегу впереди лошади" (to put the cart before the horse) (Balakova et al., 2014) is not felt at all, since it's clear what means to break correct consequence of actions.

When the interpreter translator fails to use any of represented types of phraseological correspondences, he or she has to convey figurative meaning of phraseological unit. Expression "to cut off with a shilling" relates to the fact that if father wants to disinherit his son, he cannot but mention the son in his will. In this case the son officially gets only a shilling that means disinheritance (Naumova, 2012).

Following structural-typological and function-semantic approaches, we classify phraseological units as full, partial, and zero equivalents and analogues. The carried out study allowed distinguishing the universal and the differential in two languages of different structure. The existence of large group of phraseological units of phraseothematic field "family" in phraseology of both languages refers to the area of the universal.

\section{Literature Review}

Detection of inter linguistic relations is one of major and the most interesting issue in phraseology studies, that's why it is problematized in many linguists' works. Let's dwell on the brief review of national works, which more or less describe inter linguistic phraseological correspondences and provide classification of correspondences.

Denoting various methods of English phraseological units translation into Russian, Kunin A. V. distinguished equivalents, i.e. adequate Russian phraseological unit that coincides with English turn of speech by meaning, image basis and stylistic nuance, and analogues, which are understood by him to be Russian phraseological unit adequate to the English one, but differs with its image basis.

The researcher pointed out full and partial equivalents. Full equivalents are phraseological units that coincide with phraseological units of other language by meaning, lexical composition, stylistic colouring, and grammatical structure. Partial equivalents fully convey meaning and stylistic characteristics of phraseological unit, but differ with lexical, grammatical, and lexico-grammatical features.

Solodukho E. M (Solodukho, 1989) considered the main feature of equivalence the correspondence of sense-bearing aspect of compared phraseological units. He named phraseological units that correspond by meaning full equivalents, PU that have some difference-limited equivalents. The author classified phraseological equivalents into identical equivalents, direct equivalents, synonymous equivalents, inter linguistic phraseological homonyms.

The paper of Gatiatullina Z. Z. "Comparative study of phraseological units with a component-verb of motion" became one of early works concerned with study of phraseological units involving verbs of motion (Gatiatullina, 1968). The researcher distinguished the following types of PU based on lexical-morphologic composition, quality and quantity of meanings of phraseological units with verb of motion in English, German and Sweden:

1) Phraseological equivalents, i.e. Pu found in several languages with identical morphologic and lexical composition of components, general type of grammatical structure and at least one common meaning of pu;

2) Inter-linguistic phraseological lexical variants-pu that corresponds in several languages by morphologic composition of components, type of grammatical structure, by quality and quantity of meanings and have interlinguistic lexical invariant, but differ in terms of lexis with one significant or one insignificant component.

3) Inter-linguistic phraseological morphologic variants, i.e. $\mathrm{Pu}$ that coincide in several languages by lexical-morphologic composition of components, by quality and quantity of meanings, but differ with morphologic form of one significant component;

4) Inter-linguistic lexical-morphologic phraseological variants are pu that combine elements of both lexical and morthological variance;

5) Inter-linguistic phraseological syntactical variants-pu that coincide in several languages by lexical-morphologic composition of components, by quality and quantity of meanings, but vary by the type of grammatical structure;

6) Inter-linguistic phraseological synonyms are pu that coincide by morphologic composition of significant components, by the type of grammatical structure, by common meaning of entire pu in general, but lack inter-linguistic lexical invariant. 
When studying lexical-phraseological means of Russian and Tartar languages Yusupov (1980) points out the necessity of consideration of common and specific features of compared languages. It establishes conditions for better understanding of what is typical for one or another language.

In his thesis Gavrin (1976) develops the system of lexical-semantic modifications of PU. Semantic modifications of phraseological units are understood as semantic change fixed in usage.

The author point out the following types of PU based on semantic modifications:

1) Phraseological units-doublets (or semantic modifications of phraseological units related to their lexical composition change;

2) Phraseological units-variants (i.e. Semantic modifications related to change of morphemic structure of phraseological unit);

3) Phraseological variants-synonyms (modifications related to link-words change);

4) Autonomous, or hived-off pu (or purely semantic modifications).

In accordance with modification types the researcher the following relationships of semes:

a) Relationships of complete identity (phraseological doublets);

b) Relationships of incomplete identity of first degree (phraseological variants);

c) Relationships of incomplete identity of second degree (phraseological variants synonyms);

d) Relationships of coordination (specific phraseological units);

e) Relationships of opposition (phraseological antonyms);

When studying inter-linguistic correlation of German and Russian PU, Reichstein (1980) focuses on the similarity of semantic and formal-semantic organization of phraseological units in inter-linguistic aspect.

By means of differential analysis of aspect and functional semantic correlation between specific PU of German and Russian languages the author establishes the following types of inter-linguistic phraseological relations:

1) Identity, i.e. Full coincidence of aspect organization and comprehensive meaning;

2) Lexical variance or structural synonymy (full coincidence of comprehensive meaning and syntactical organization when component composition is of incomplete identity);

3) Ideographic synonymy (incomplete identity of comprehensive significative meaning due to compared pu's specific semantic features);

4) Hyper hyponymy, i.e. Incomplete identity of comprehensive significative meaning due to specific semantic features of one of compared pu;

5) Stylistic synonymy (complete identity of comprehensive meaning due to stylistic differences);

6) Homonymy and polysemy (identity of aspect organization with more or less differences in comprehensive meaning);

7) Enantiosemy, i.e. Identity of aspect organization with opposite comprehensive meaning.

As we can see, Reichstein, A. D. studies not only relations of complete identity and complete different but also intermediate relations or relations of incomplete (partial) identity. Stated types of inter-linguistic phraseological relations are found when comparing languages: a) in separate aspects of formal-semantic organizations; b) in their comprehensive content, i.e. in significative-denotative and connotative meanings (Linguistic encyclopedic dictionary, 1990).

Dolgopolov (Dolgopolov, 1973) analyzes the following types of inter-linguistic relationships: 1) inter-linguistic phraseological equivalence; 2) inter-linguistic phraseological variance; 3) inter-linguistic phraseological homonymy; 4) inter-linguistic phraseological synonymy.

The linguist includes multilingual phraseological units that coincide by their image, meaning and stylistic colouring, correlated by component composition and structural-grammatical organization to intra-linguistic phraseological equivalents, for example, (eng) hold out a hand-(ger) die Hand reichen.

The feature of intralinguisitc phraseological equivalence at semantic level is identical meaning or semantic invariant of multilingual phraseological units. Generally, Dolgopolov Y. A. states that the notion of phraseological equivalence is conditional.

As it's evident from the foregoing, linguistic literature provides various classifications of phraseological units by 
degree of their equivalence. Approaches vary depending on adhering to translation theory (for example, Kunin) or structural typological similarities and differences (Solodub \& Reichstein). Nonetheless, both approaches distinguish two fundamental relations-equivalents and analogues (correspondences), which are considered types of equivalents in case of the latter approach.

\section{Methods}

In this paper we use comparative-typological method, method of phraseological identification by Kunin (1986), contrastive method, transformational analysis method and universal differential method designed by Gatiatullina (1982).

The material of the study is presented with examples taken by the method of continuous sampling from monolingual and bilingual phraseological dictionaries.

In our study we hold structural-typological and functional-semantic approaches trying to find out the equivalence of PU. Thus, we divide equivalents into full, partial and zero (lacunary) ones.

The inter-linguistic phraseological equivalents cover multilingual PU coincided by their form, meaning and stylistic colouring and correlated by component composition and structural and grammatical organization.

When analyzing phraseological equivalents we consider the following parameters:

1) Aspect correlation;

2) Component composition;

3) Syntactic structure;

4) Functional-semantic correlation;

5) Comprehensive meaning of fu;

6) Stylistic colouring.

\section{Results}

In our study we have pointed out the following types of phraseological correspondences: full equivalence, partial equivalence, zero equivalence and phraseological analogues. Let's examine them in detail.

\subsection{Full Equivalence}

The full equivalence is understood to be semantic and lexical equivalence of components of phraseological units. Taking into account the fact that we consider languages of different systems (English and Turkish), the full equivalents in these languages have no absolute coincidence at grammatical and morphological levels.

As the examples of equivalence we list such locutions as (eng.) bring into the world $=$ (turk.) dünyaya getirmek and (eng.) come into the world = (turk.) dünyaya gelmek. The present phraseological units have differences in grammatical structure: firstly, the English preposition into can be expressed in Turkish with affix -ya; secondly, in English FU the verb is located in the beginning of the unit, while in Turkish - at the end (Yusipova, 2005).

The full inter-language equivalence is presented with such PU as (eng.) family planning and (turk.) aile planlamast. However, such a FU as the new arrival is of equal sounding in both languages-(turk.) yeni doğan. The grammatical structure of the FU is $\mathrm{Adj}+\mathrm{N}$.

The group of full equivalents can also be added with such a PU as (eng.) affair of the heart = (turk.) gönül işleri. We have here semantic and lexical coincidence of phraseological units. The analysis of the present PU of English language has shown that English lexeme affair (has five meanings according to English-Russian dictionary of Muller (2004)) fits Turkish işler, while lexeme heart is the same as gönül. The only difference is word order- "affair + heart" in English and "gönül + işleri" ("heart + affair") in Turkish.

The comparison of phraseological units with identification of full equivalents in English and Turkish languages has shown that only substantive phraseological units of compared languages are subject to coincidence.

\subsection{Partial Equivalents}

The partial equivalents include semantically equivalent phraseological units of English and Turkish languages having definite differences in terms of expression. The differences cover structural-grammatical organization and component composition.

There are some examples: English PU child of shame and Turkish günah mahsulu with general meaning "illegitimate" ("bastard") differ with its components; literal translation of the Turkish unit is "fruit of shame", i.e. lexems child and mahsul are different. The "sin" lexeme confirms negative position towards bastardy in both 
languages.

Let's analyze phraseological units mother's darling and ana kuzusu. Lexems darling meaning "favourite one" in English and kuzu- "lamb" in Turkish indicate partial coincidence of the phraseological units in terms of expression.

The following example for partial equivalence: (eng.) one's flesh and blood = (turk.) kan bir can bir. The phraseological units differ with the components flesh (eng.) and can- "soul" (Turk.). Moreover, differences affect structural organization of the phraseological units as well: (eng.) $\mathrm{N}+\mathrm{Prep}+\mathrm{N}$, (Turk.) Num $+\mathrm{N}+\mathrm{Num}+$ $\mathrm{N}$ (where Num-numeral).

Phraseological units (eng.) fall in love and (Turk.) aşka gelmek have common meaning.

Above-mentioned phraseological units differ with verbal components fall and gelmek - "to come".

Partial phraseological equivalents are the following: (eng.) be born under a lucky star and (Turk.) yıldızı barlşı (Yusipova, 2005). The phraseological units coincide semantically since the notion of "happy man" is expressed in both languages using the image of star. However, it's a communicative PU in English, and an adjectival one-in Turkish.

Thus, differences are found in grammatical, structural organization and slight difference of lexical components in partially equivalent phraseological units, however image base in such PU is the same.

\subsection{Zero Equivalence}

More accurate name of the phenomenon of zero equivalence is lacunarity. Phraseological lacunarity reflects absence of phraseological equivalent to impart meaning of $\mathrm{PU}$ of other language.

It's known that language is one of forms of reflection of objective reality, and in different languages perception and understanding of the world are different; this phenomenon is best demonstrated when comparing languages of different structures, for example, English and Turkish.

Sadykova represented the most complete understanding of the notion of phraseological lacunarity (Sadykova, 1989). According to the author, phraseological lacunarity is bilateral category that includes features of the universal and the unique as well.

Artemova (2013) calls zero equivalence no-equivalent phraseology and established special indexes of correlation between the type of phraseological equivalence and the form of national specifics demonstration.

At phraseological level lacunarity is mainly caused by specifics of practiced religion of one or another nation, canons of confession. For example, in Turkish there's a Shariat custom involving bride-show with a fiance, and this phenomenon is expressed in a phraseological unit that is lacunal in English-görücüye çıkmak.

Turkish doesn't know expression "announce names of bridal couple in a church three times (in order to reveal obstacles to marriage)", and there's such an expression in English—ask (call, read) the banns (Zhukov, 2010).

Traditionalism is reflected in phraseological locutions of English, which are absent in Turkish: Lares and Penates - hearth and home; an Alruna wife - goddess hearth. Lares and Penates were gods of hearth in the period of Roman Kingdom, and Alrunas - gods of hearth in the period of ancient German paganism (Kunin, 1984). In general, phraseological units with proper names are the most difficult to translate into other language.

Besides the mentioned PU, the following English PU that lack in Turkish can be named: Darby and Joan - an old loving couple; May and December - an old man and a young wife; Strephon and Phyllis - a sentimental young man and his beloved.

Strong difference in cultures of England and Turkey is observed when analyzing phraseological units that define relations between the man and the woman within marriage and, particularly, marriage. For example, there are such PU in English as grass widow and golf widow. There's no such PU in Turkish, because, in our opinion, it's not typical in Islamic culture to leave a married woman alone for a long time. The lack of the second PU golf widow is explained by the fact that golf is not popular in Turkey.

In English there's the following PU: a bachelor girl. In our opinion, this phraseological unit emphasizes equality between the sexes in English culture, but superiority of the man over the woman, dependence of the latter on her husband in Turkish culture. The examples are the following: evine göre pişir aşını, erine göre bağla başını-be obedient wife and house-proud woman; baba ekmeği zindan ekmeği, koca ekmeği meydan ekmeği-"a married woman should materially depend on her husband and not rely on parents' help". However, in English there's uncomplimentary attitude to a wife who sets foot on her husband's neck: it is a sad house where the hen crows louder than the cock. 
Talking about Turkish nation attitude towards mother is full of respect. The following PU that lack in English are the evidences:

Ana hakkı Tanrı hakkl-mother's rightness is god's rightness;

A ğlarsa anam ağlar, başkast yalan ağlar - mother is the closest person;

Ana gibi yar olmaz, Bağdat gibi diyar olmaz-there's no person better than mother as there's no city more beautiful than Bagdad. (Yildirim, 2010; Aydın, 1972)

Speaking about marriage, ironical attitude is demonstrated in English culture:

Double harness;

Ball and chain;

Jump over the broom stick;

Wedlock is a padlock. (Kunin, 1984)

All these phraseological units are unknown to Turkish language.

Absolute lacunas in English are PU of Turkish language with the "daughter in law" seme. Relations of daughter in law and her husband's parents became ingrained in phraseological fund of Turkish. Probably, it's caused by living daughter-in-law and her husband's parents beneath the same roof from the beginning of time. Besides, she had to demonstrate skillful housekeeping of hers. The image of daughter-in-law creates, curiously enough, impression of a brisk and even frightening husband's parents woman. For example, we found three phraseological units that mean "daughter-in-law rules the roasts in home": gelini ata bindirmişler, "ya nasıp" demiş; gelin hall getirir, serer kendi oturur; gelin atta buyuruk Hak'ta (Yildirim, 2010).

Known enmity between daughter-in-law and mother-in-law is also reflected in Turkish proverbs and sayings. General meaning of PU given below is that "daughter-in-law and mother-in-law never get along together": kaynana ocu, oğlu cici; kaynana pamuk ipliği olup raftan düşse gelinin başını yarar; the phraseological unit oglan anası kapı arkasl, klz anası minder kabası is translated into "for daughter-in-law mother-in-law is as well as nobody". (Yildirim, 2010)

\subsection{Analogues}

Following Kunin A. V., we classify analogues as set expressions, which are adequate by meaning to source language PU, but "differ from it completely or partially by image basis" (Kunin, 1986). Analogues convey specific images or notions different in different languages. One and the same reality of compared languages can be transferred by different lexemes; differences can be observed in structural-grammatical organization. Their semantic commonness unites these expressions of different languages in one type of inter-linguistic relations. For example, the PU of English "as the tree, so the fruit", and the Turkish one "ağaca çıkan keçinin dala bakan oğlağı olur"-literally, "a goat that climbs trees will have a goatling looking at branches". Such phraseological units are caused by national peculiarity of languages under study.

The topic of national-cultural specifics can be called traditional for studies in the area of phraseology. Sometimes differences in phraseology of different languages cannot be described in lexical terms alone. Dobrovolsky (1997) suggests an interesting idea that plane of content of some phraseological unites includes specific component, which conditionally can be called cultural.

Significant inter-linguistic differences that record mismatches in interpretation of certain fragments of reality by different linguistic communities can be detected addressing locution's inner form.

In respect to the issues of the study let's examine three grounds for inter-linguistic differences distinguished by the author: cognitive grounds, cultural significance, and symbolic component. In our opinion, this development is applicable to explain causes of linguistic analogues appearance.

1) Cognitively significant differences arise where conceptual metaphors do not coincide. Answer to the question why some foreign idiomatic expressions are clear and can be borrowed, and others cannot, largely depends on whether the target language has conceptual metaphors specific for one or another language expression. For example, in Turkish there's an idiom evde kalmak; it's literally translated as "stay home". In English it will be "miss one's market".

English phraseological unit "blue blood" has no identical equivalent in Turkish language. The notion of "noble origin" in Turkish language is reflected in the PU soylu soplu (literally, "a high-born person").

In these cases one may consider cognitively conditional non-coincidences between English and Turkish 
languages. Such differences indicate specific nature of understanding certain fragments of reality by corresponding linguistic communities.

2) According to Dobrovolsky D. O., conceptual differences of phraseological units of compared languages, can be considered culturally marked, if they reveal culturally significant consequences or are perceived conditional ones by culturally significant causes. For example, Turkish PU anası kadır gecesinde doğurmuş corresponds to English be born with a silver spoon in one's mouth or be born with a caul on one's head. In Islam kadlr gecesi is the $27^{\text {th }}$ night of Ramazan, Night of Determination (when Koran was sent to Mohammed).

3) If there's a symbolic component, cultural significance increases ("cross" in "bear one's cross"). The author gives as an example locutions of several European languages with symbolic component "seven" and Japanese locutions correlated with them by meaning, in which notion "eight" functions similarly.

Lexeme "home" is the example of symbolic component in the structure of English phraseological units' group "family":

Charity begins at home;

Keep the home fires burning;

To make oneself at home. (Zhukov, 2010)

In Turkish analogical component with meaning "home"- ev—is a symbolic component of PU:

Ev bark - hearth and home;

Ev açmak-start a family;

Ev halkl-the whole family;

Evine göre pişir aşını, erine göre bağla başını- "be obedient wife and house-proud woman" (preaching);

Ev yapmak — to reconcile spouses. (Aydın, 1972)

\section{Conclusions}

When comparing phraseological units of English and Turkish languages we have considered the following types of inter-language relations: full equivalents, partial equivalents, zero equivalents and analogues.

The full inter-language equivalents imply semantic and lexical equivalence of phraseological components with correspondence or insignificant difference of grammatical and morphologic levels, with regard to the fact that compared in our study English and Turkish languages are languages of different systems, genetically non-kindred ones.

Partial equivalents are PU that have certain differences in plane of expression, but coincide by their meaning.

Zero equivalence or lacunarity reflects absence of phraseological equivalent to convey PU meaning of other language.

Full inter-linguistic equivalents are presented with small amount of phraseological units in both languages. The majority of complete phraseological equivalents conform to the ideogram "function of family continuation", which is evidence of common perception and understanding of this phenomenon by both nations. Full equivalents are only substantive PU with structures $\mathrm{Adj}+\mathrm{N}, \mathrm{N}+\mathrm{N}$.

Partial equivalents include PU with difference in structural-grammatical organization, with greater difference of lexical components, but with common image basis.

Zero equivalence reflects inadequate understanding of reality objects in compared languages. Lacunas appear when translating fusions, i.e. phraseological units that lost their inner form and have indecomposable non-motivated meaning. As a rule, phraseological units of absolute lacunarity are based on proper names, national customs and rules, established by religion of one or another nation. Proverbs and sayings are most subject to creating lacunas in phraseology of other languages.

We include phraseological analogues to the type of interlinguistic relations. Analogues are understood to be set expressions, which are adequate by meaning of original language PU, but completely or partially differ from it by image. Analogues impart specific, different images or notion of different nations. One and the same reality can be delivered with different lexemes in different languages; differences may affect structural-grammatical organization of PU. It's impossible to describe appearance of analogues only in semantic terms. We see solution of this issue in the development of Dobrovolsky D. O. on the grounds of inter-linguistic differences. Application of this development to our study provides clean-cut explanation for the cause of inter-linguistic analogues 
appearance. Following Dobrovolsky D. O., we point out three causes: cognitive grounds, cultural significance, and symbolic component.

1) Cognitively significant differences arise where conceptual metaphors do not coincide;

2) Conceptual differences of phraseological units of compared languages, which reveal culturally significant consequences are named culturally marked.

It has become clear that definition of family, its structure, intrafamilial interpersonal relationships is common for English and Turkish languages. Similarity of PU of defined topic indicates certain commonness of associative-image thinking of given languages speakers. Differences in phraseological body of the languages under study are exposed in structural-grammatical organization caused by dissimilitude and distance of English and Turkish languages. Substantial domination of phraseological systems' expressions that present specifically national formations is explained by distinction in historical experience and cultural identity of the language communities.

\section{References}

Alper Yildirim Yeni Atasozleri ve Deyimler Sozlugu (p. 558). (2010). Istanbul: Bilge Kultur Sanat.

Artemova, O. A. (2013). Belorussian-English interlinguistic phraseological equivalence in theoretical and applied aspects. Aktualnye voprosy perevodovedeniya i praktiki perevoda.

Balakova, D., Walther, H., Venzhinovich, N. F., Gutovskaya, M. S., Ivanov, E. E., \& Mokienko, V. M. (2014). Contribution of Biblical wisdom: Biblical winged expressions and aphorisms in Russian, English, Belorussian, German, Slovak, and Ukrainian (p. 208). Mogilev: Moscow state university named after Kuleshov A. A.

Dobrovolsky, D. O. (1997). National and cultural features in phraseology. Voprosy yazykoznaniya, 6, 37-48.

Dolgopolov, Y. A. (1973). Contrastive analysis of somatic phraseology (based on Russian, English, and German) (Cand. Sc. thesis. Kazan) (p. 263).

Gatiatullina, Z. Z. (1968). Comparative study of phraseological units with a component-Verb of motion (Synopsis of Cand. Sc. Thesis) (p. 16). Moscow.

Gatiatullina, Z. Z. (1982). Comparative typology of the lexical systems of English and Tartar (p. 104). Moscow: Moscow State Teachers College named after Lenin V. I.

Gavrin, S. G. (1976). The issue of functioning and development of phraseological fund of the Russian language in the context of general questions of phraseology theory (based on phraseology of the second half of the $19^{\text {th }}$ and $20^{\text {th }}$ centuries) (Thesis of DLitt) (pp. 278-279, p. 545). Leningrad.

Kunin, A. V. (1984). English-Russian phrase book (p. 942). Moscow: Russky yazyk.

Kunin, A. V. (1986). Modern English phraseology course: Textbook for institutes and faculties of foreign languages (p. 336). Moscow: Vysshaya shkola.

Kunin, A. V. (1987). Regarding phraseological definition. Voprosy angliiskoy frazeologii (communicative and phraseological aspects). In Collection of scientific papers (pp. 109-118, p. 148). Moscow: Vysshaya shkola.

Linguistic encyclopedic dictionary (p. 172). (1990). Moscow: "Sovetskaya Entsiklopediya".

Muller, V. K. (2004). New English-Russian dictionary (Issue 11, p. 946). Moscow: Russky yazyk-Media.

Naumova, I. O. (2012). Dictionary of phraseological similarities of Russian and English (in the context of languages convergence) (p. 138). Kharkov: Kharkov National Academy of Municipal facilities.

Oy Aydın Tarih Boyunca Türk Atasözleri (p. 398). (1972). İstanbul: Turkiye Is Bankasi Kultur Yayinlari.

Molotkov, A. I. (Ed.). (1986). Phrase book of the Russian language (p. 543). Moscow: Russky yazik.

Reichstein, A. D. (1980). Contrastive analysis of German and Russian phraseology (p. 143). Moscow: Vysshaya shkola.

Sadykova, G. Z. (1989). Interlinguistic phraseological lacunarity and means of its compensation (Synopsis of a thesis of Cand. Sc.) (p. 16). Kazan.

Solodub, Y. P. (1997). Contrastive analysis of structure of lexical and phraseological meanings (No. 5, pp. 43-54). Filologicheskie nauki.

Solodukho, E. M. (1989). Theory of phraseological rapprochement (p. 269). Kazan. 
Zvegintsev, V. A. (Ed.). (1981). The new in foreign language studies: Collected works. In V. A. Zvegintsev (Ed.), Linguistic semantics (Issue 10, p. 567). Moscow: Progress.

Yusipova, R. R. (2005). Turkish-Russian dictionary. Russky yazyk-Media Gold.

Vinogradov, V. S. (2001). Introduction to translation studies (general and lexical issues) (p. 224). Moscow: Russian Academy of Education General Secondary Education Institute Press.

Yusupov, R. A. (1980). Lexical-Phraseological means of Russian and Tatar languages (p. 8, p. 55). Kazan.

Zhukov, A. V. (2010). Russian lexical-Phraseological dictionary (Biblio) (p. 704). Moscow: AST: Astrel.

\section{Copyrights}

Copyright for this article is retained by the author(s), with first publication rights granted to the journal.

This is an open-access article distributed under the terms and conditions of the Creative Commons Attribution license (http://creativecommons.org/licenses/by/3.0/). 